\title{
PALEOSTRESS AND OUTCROP FRACTURE ANALYSIS ALONG HIMALAYAN FOOTHILLS (EASTERN SALT RANGE), POTWAR PLATEAU, NW HIMALAYA, PAKISTAN
}

\author{
Hassan MEHMOOD, Muhammad Armaghan Faisal MIRAJ * and Naveed AHSAN
}

Institute of Geology, University of the Punjab,Quaid-i-Azam Campus- 54590, Lahore, Pakistan

*Corresponding author's e-mail: armghan.geo@pu.edu.pk

\begin{tabular}{|c|c|}
\hline ARTICLE INFO & ABSTRACT \\
\hline Article history: & \multirow{10}{*}{$\begin{array}{l}\text { The Salt Range (SR) is an ENE-WSW trending fault bend fold that form the range front of the } \\
\text { Himalayan fold and thrust belt in Pakistan. The research is carried out in the Eastern Salt Range } \\
\text { (ESR) with the objective to determine the paleostress inversion from reduced stress tensors by } \\
\text { using fracture data. The surface morphology of the fold is predominantly shaped by Eocene } \\
\text { limestone that provide best exposure of joint surfaces that can be used for kinematic and dynamic } \\
\text { analysis. We adopted a classical circle inventory method in the field and collected orientation data } \\
\text { (dip amount, direction, and strike) from } 7 \text { localities (outcrop stations) of the Eocene Sakesar } \\
\text { Limestone. Three prominent fracture trends are present in the study area namely, FS-1; (E-W), } \\
\text { FS-2; (ENE-WSW) and FS-3; (NNE-SSW). For stress analysis and data processing we used the } \\
\text { Tensor Program of Delvaux and Sperner ( } 2003 \text { ) and calculated seven stress fields by the Right } \\
\text { Dihedron Method. The orientations of the principal stress axes ( } \sigma 1, \sigma 2, \sigma 3 \text { ) and Stress Ratio (R) } \\
\text { depicts } 61 \text { (Shmax) and } 62 \text { are sub-horizontal while } 63 \text { is vertical in all stress tensors. The } \\
\text { paleostress results show that } \sigma 1 \text { (Shmax) oriented NNE-SSW belonging to a compressive regime. } \\
\text { It is suggested that } \sigma 1 \text { developed more or less perpendicular to the trend of SRT and other relevant } \\
\text { structures in the Potwar Plateau. }\end{array}$} \\
\hline Received 4 February 2021 & \\
\hline Accepted & \\
\hline Available online 25 March 2021 & \\
\hline Keywords: & \\
\hline Paleostress inversion & \\
\hline Fracture analysis & \\
\hline Eastern Salt Range & \\
\hline Sakesar Limestone & \\
\hline NW Himalaya & \\
\hline
\end{tabular}

\section{INTRODUCTION}

Paleo-stress fields in the Earth crust can be inferred from numerous types of stress precursors like earthquakes, land sliding, and faulting/fracturing (Delvaux and Seperner, 2003). Brittle structures (faults/fractures) are the consequences of the tectonic forces which are handy to reconstruct the orientations of the stresses that were active in the past (Igwe and Okonkwo, 2016; Kaven et al., 2011). When sedimentary rock layers are subjected to stress either compressional or extensional it has a direct relationship with cracked planes and stress orientations. Stress ellipsoid axes outline the behavior of the rocks under stress and describe the magnitudes of the principal stresses (Kaymakci, 2006). Fractures are the most common outcome of tectonic stresses applied to rocks and hence are vital and well-founded indicators of paleostress/strain patterns in deformed sedimentary rocks (Lacombe et al., 2011; Bellahsen et al., 2006; Engelder, 1987; Friedman, 1975). Fracture network or connectivity provides pieces of evidence about the ancient stress when rocks had suffered deformation (Hugmanand Friedman, 1979; Handinet al., 1963). It can be calculated from fracture parameters (dip, strike, relative abundance) and the relationship between the fracture sets (Nelson, 2001).
The study area is located in the Salt Range that is formed above Salt Range thrust (SRT) that define the southern boundary of the Potwar (Fig. 1). The SRT has been activated several times from Early Pliocene to Holocene to accomodate continued convergence between Indian and Eurasian Plates (Cortés-Aranda et al., 2016; Grelaud et al., 2002; Cotton and Koyi, 2000; Jadoon et al., 1997; Burbank and Beck, 1989; Baker et al., 1988). Dominant structural trends of the Salt Range and Potwar are is NE-SW and E-W deduced from axial plane of folds and strike of major thrusts. The Potwar and Salt Range boundaries are defined by two strike-slip faults: sinistral Jehlum Fault (JF) on the eastern margin while dextral Kalabagh Fault (KF) in the west. The northern boundary of the Potwar is marked north dipping Main Boundary Thrust (MBT) (McDougall and Khan, 1990; Lillie et al., 1987; Yeats et al., 1984; Fig. 1). The main objective of the research is to get a better understanding of paleo-stress conditions of the project area and to calculate the reduced stress tensors that can explain the sense of movement along with the shear fractured planes. For this purpose, we collected fracture data of Early Eocene rock units (Sakesar Limestone) from seven outcrop sections (Eastern Salt Range). For numeric stress field calculations, we used the Tensor ${ }^{\mathrm{TM}}$ 


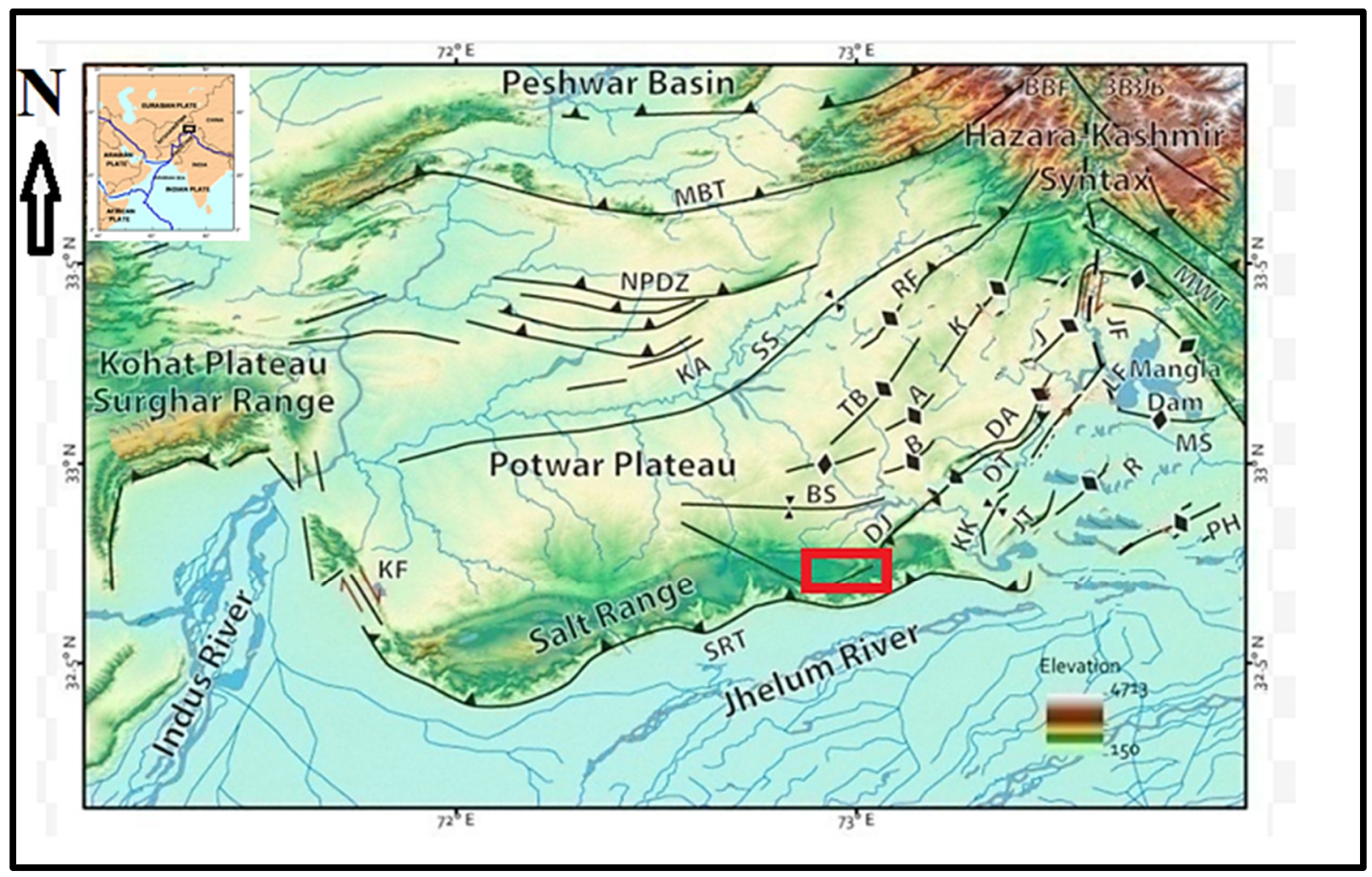

Fig. 1 Location of Study Area (Red Rectangle) and major Structural Elements of the Salt Range-Potwar Basin, NW Himalaya, Pakistan (Modified from Corties-Aranda et al., 2016); (SRT= Salt Range Thrust, $\mathrm{KF}=$ Kalabagh Fault, JF=Jehlum Fault, NPDZ= Northern Potwar Deformed Zone, DJ=Dil Jabba Fault, MBT=Main Boundary Thrust).

program (Delvaux and Sperner, 2003) and calculated seven stress tensors by Right Dihedron Method.

\section{GEOLOGICAL SETTINGS}

The formation and development of Himalaya is the result of convergence between Indian and Eurasian Plates (Searle et al., 2019; Myrow et al., 2019; Van Hinsbergen et al., 2012; Yin, 2010; Hodges, 2000; Coward et al., 1986; Tapponnier, 1986; Molnar, 1986; Powell, 1979; Molnar and Tapponnier, 1977; Powell and Conaghan, 1973). Complete consumption of NeoTethys Ocean below Eurasian Plate during Eocene and subsequent convergence resulted in the formation of $\mathrm{N}$-dipping thrusts with their tectonic transport southward (Ingalls et al., 2016; Treloar et al., 1992; Coward et al., 1988; Searle et al., 1987; Tapponnier et al., 1986; Tahirkheli, 1979, 1982; Gansser, 1964, 1981).The Salt Range is $150 \mathrm{~km}$ ENE-WSW trending fold and thrust belt which is developed on the frontal margin of the Himalayan Orogen (Coward et al., 1986; Kazmi and Rana, 1982; Yeats and Lawrence, 1982) (Fig. 2). SRT is correlated with Himalayan Frontal Thrust (HFT) of the northwestern Himalaya and Main Frontal thrust (MFT) of the Central Himalaya.

The SRT separates the Punjab Plains from the deformed Himalayan Fold and Thrust Belt restricted by two strike-slip faults at their eastern and western margins (McDougall and Khan, 1990; Gee, 1980,
1989) (Fig. 2). KF is an NNW trending transpressional dextral strike-slip fault which truncates the western edge of the Salt Range (Fig. 2). It has juxtaposed the Indian Plate marine sediments over the recent Indus River deposits (McDougall and Khan, 1990). Its orientation indicates that it may probably be underlain by the lateral ramp (Butler et al., 1987). JF is a sinistral strike-slip fault that has terminated the eastward extension of the Potwar fold and thrust belt (Baig and Lawrence, 1987). There are major three deformational zones along the Salt Range and Potwar Plateau from North to South: Northern Deformed PotwarZone (NPDZ), Soan Syncline, and the Salt Range (Southern Potwar) (Cotton and Koyi, 2000).

The most prominent structural element in the Eastern Salt Range is the NE-SW trending Dil Jabba Back Thrust (Fig. 1). It extends in the northeast direction and thrusted the Salt Range Formation on the Miocene Murree Formation (Gee, 1980). In the Salt Range and Potwar Basin four major tectonostratigraphic depositional units bounded by unconformities are reported (Fig. 2) i.e. Indian Shield (Precambrian meta-sediments), Eocambrian Halite sequence, Platform rocks (Cambrian-Paleogene) and Molasse sediments (Miocene-Quaternary) (Mugnier and Huyghe, 2006; Grelaud et al., 2002; Blisniuk et al., 1998; Gee, 1980; Davies and Crawford, 1971). The oldest stratigraphic unit exposed is the Salt Range 


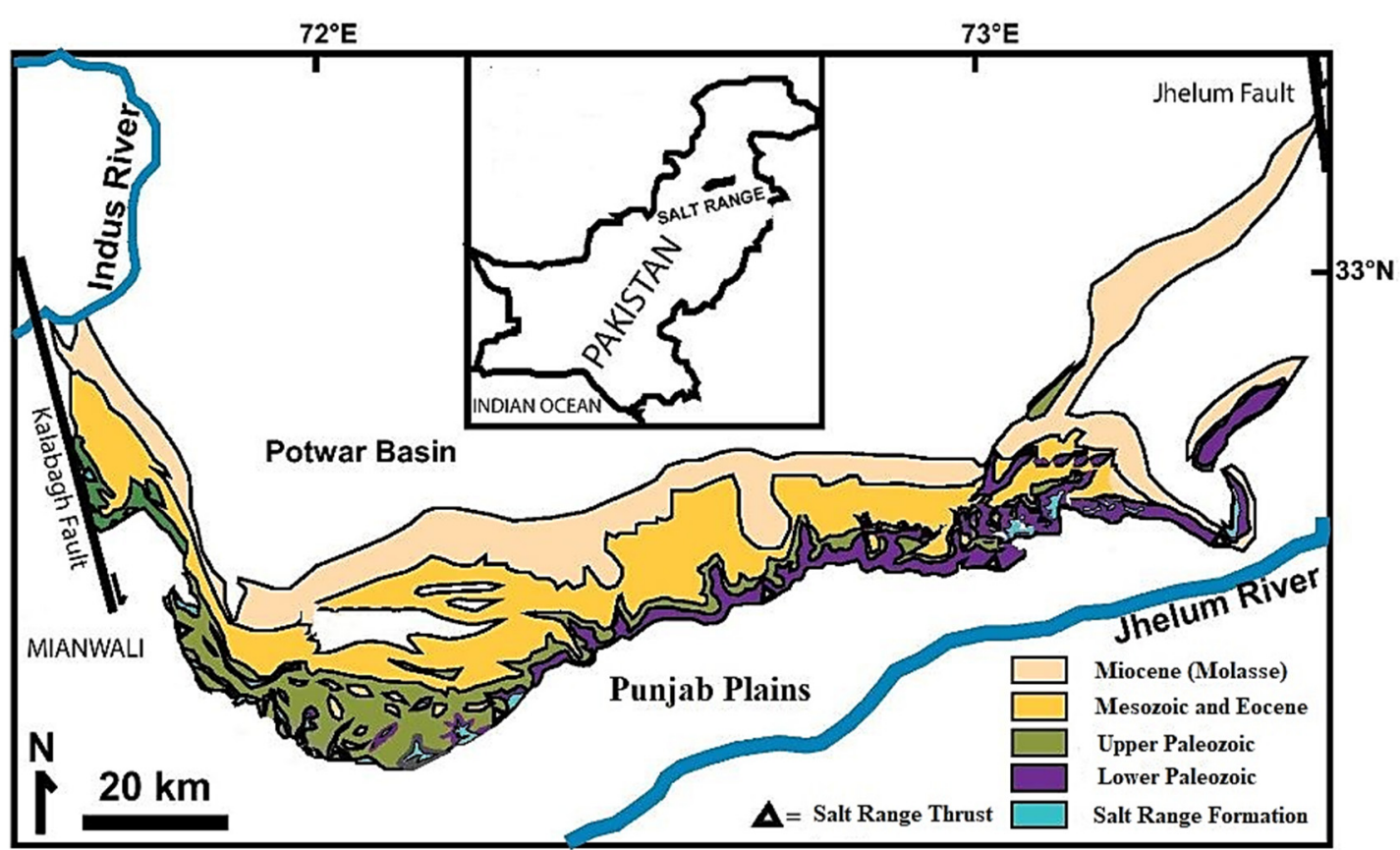

Fig. 2 Geological Map of the Salt Range, Potwar Plateau, NW Himalaya Pakistan showing prominent tectonostratigraphic units (Modified from Hughes et al., 2019; Gee, 1945).

Formation (Eocambrian) which unconformably overlies the Precambrian basement rocks of Indian Shield (Gee and Gee, 1989; Shah, 1977). The Early Eocene strata (Nammal Fm, Chorgali Fm, and Sakesar Limestone) are well exposed in the Salt Range that cover the Precambrian to Paleocene stratigraphic succession of the Salt Range. (Gee and Gee, 1989).

\section{DATA AND METHODOLOGY}

In order to evaluate the brittle deformation history and paleostress inversion, fractures are measured from Sakesar Limestone outcropping in the Eastern Salt Range. The 350 individual fractures are recorded from the 9 localities (43 outcrop stations) to get a better understanding of the paleostress conditions in the study area (Table 1; Fig. 3). The method adopted in the field for data collection was the Circle Inventory. Collected data type includes (strike and dip orientations) of the fracture planes. For data processing and determination of the principal stress axes $(\sigma 1, \sigma 2, \sigma 3)$ and stress ratio $\mathrm{R}=(\sigma 2-\sigma 3) / \sigma 1-\sigma 3)$ we used Win Tensor ${ }^{\mathrm{TM}}$ (Delvaux and Sperner, 2003) tool and calculated stress inversion by the Right Dihedron Method (RDM). Win Tensor ${ }^{\mathrm{TM}}$ is an interactive computer-based program used for statistical analysis of stress inversion by using fault slip, fracture, and focal mechanisms by Right Dihedron and Optimization methods. RDM defines two compressional and two extensional right dihedra essentially perpendicular to the fault/fracture plane and the slip direction (Lisle, 1988; Mckenzie, 1969). It permits the estimation of principal stress axes orientations, stress ratio ( $\mathrm{R})$, and stress regime for a given number of structural discontinuities.

\section{FIELD OBSERVATIONS}

For a better understanding of the structural complexities and reliable results, a maximum number of fractures (dip/strike) are recorded in the field. Based on field data plotted on the Rose Diagram mainly three sets of fracture systems are identified; FS-1 (E-W), FS-2 (ENE-WNW), and FS-3 (NNE-WSW) (Fig. 4; Table 1). A detailed summary of fracture analysis is enlisted in Table 1. Rose Diagrams (Fig. 6) and stereonet plots (Fig. 7) suggest that most fractures in the study area are present along the strike in the NE-SW direction. Moderate to highly dense fracture pattern observed and the intensity of the deformation enhances towards fault zone while at some location's fractures were filled with calcite and chert (Table 1; Figs. 4b, f). These fracture sets were used for paleostress inversion to obtain reduced stress tensors. For full stress tensor four parameters are taken into consideration $\sigma 1$ (principal stress), $\sigma 2$ (mean stress), $\sigma 3$ (min stress), R (stress ratio).

\section{PALEOSTRESS ANALYSIS}

\subsection{THEORY AND BACKGROUND}

The frequent and most widely used method for paleostress inversion includes the faults slip data with slickensides pointing the direction of the slip (Ramsay and Lisle, 2000; Angelier, 1994; Angelier, 1989; Aleksandrowski, 1985). Application of this method is based on Wallace-Boot Hypothesis and later 
Table 1 Detailed description of Fracture Analysis in the study area.

\begin{tabular}{|c|c|c|c|c|c|c|}
\hline Site ID & Locality & Rock Unit & Fracture Set (FS) & Dip & Strike & Fracture Infilling \\
\hline 001 & Nilawahan & Limestone & $\begin{array}{l}\text { FS-2 } \\
\text { FS-3 }\end{array}$ & $15-40$ & $60-80$ & None \\
\hline 002 & Mallot & Limestone & FS-3 & $10-12$ & $310-320$ & Calcitic Veins \\
\hline 003 & Warala & Limestone & $\begin{array}{l}\text { FS-1 } \\
\text { FS-3 }\end{array}$ & $5-9$ & $40-45$ & Calcitic Veins \\
\hline 004 & $\begin{array}{l}\text { Katas Temple } \\
\text { Road }\end{array}$ & Limestone & FS-2 & $6-11$ & $340-350$ & None \\
\hline 005 & $\begin{array}{l}\text { Choa Saidan } \\
\text { Shah }\end{array}$ & Limestone & FS-3 & $30-40$ & $10-40$ & Chert \\
\hline 006 & Sultanpur & Limestone & FS-3 & $10-12$ & $40-50$ & Calcitic Veins \\
\hline 007 & Saloi & Limestone & $\begin{array}{l}\text { FS-1 } \\
\text { FS-2 } \\
\text { FS-3 }\end{array}$ & $5-11$ & $25-60$ & None \\
\hline 008 & Takwan & Limestone & FS-2 & $10-30$ & $55-60$ & Ferruginous \\
\hline 009 & Dill Jabba & Limestone & $\begin{array}{l}\text { FS-1 } \\
\text { FS-2 } \\
\text { FS-3 }\end{array}$ & $15-30$ & $40-60$ & None \\
\hline
\end{tabular}

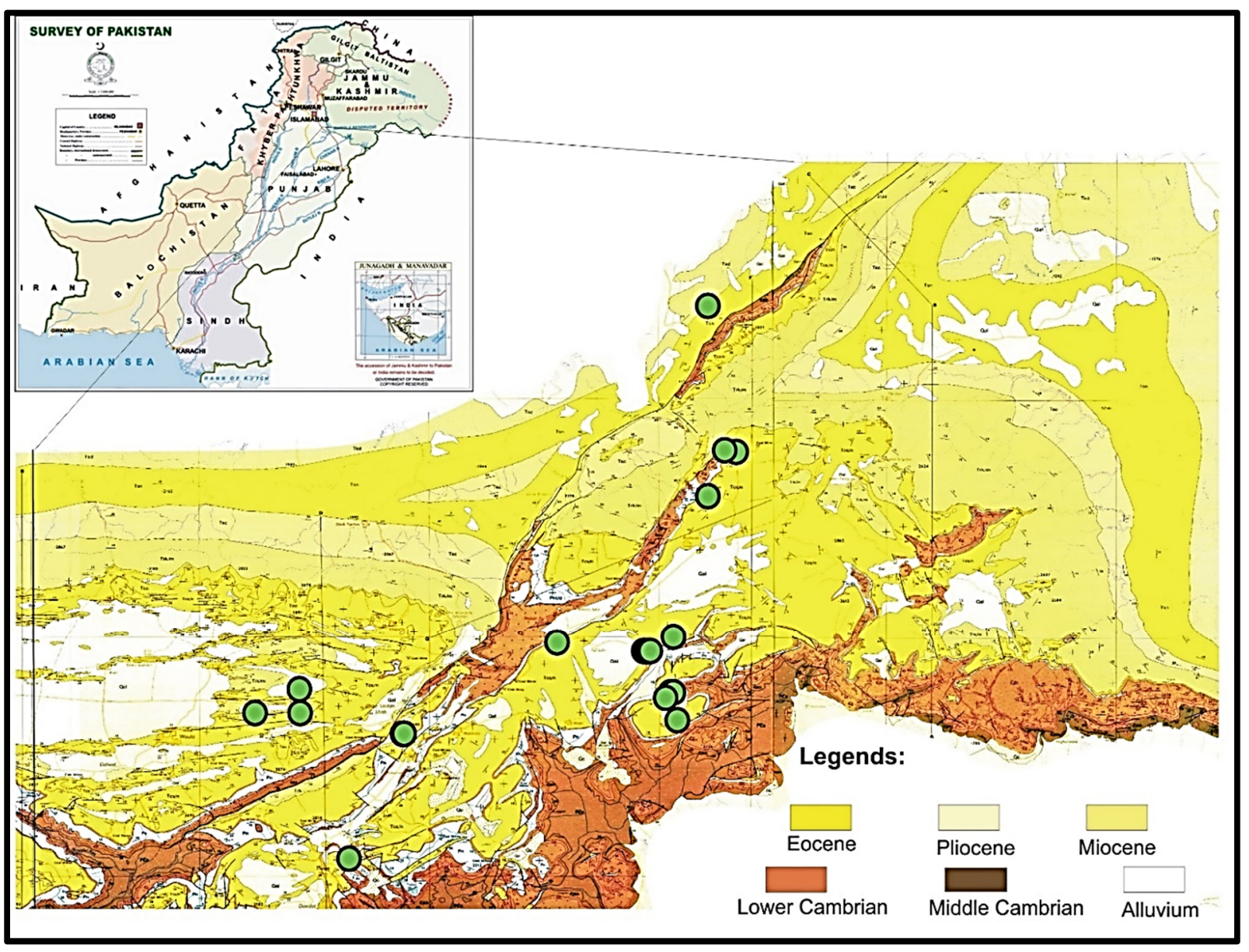

Fig. 3 Geological Map of the Eastern Salt Range (Potwar Basin) showing fracture data collection sites used for paleostress analysis (Modified after Gee, 1980). 


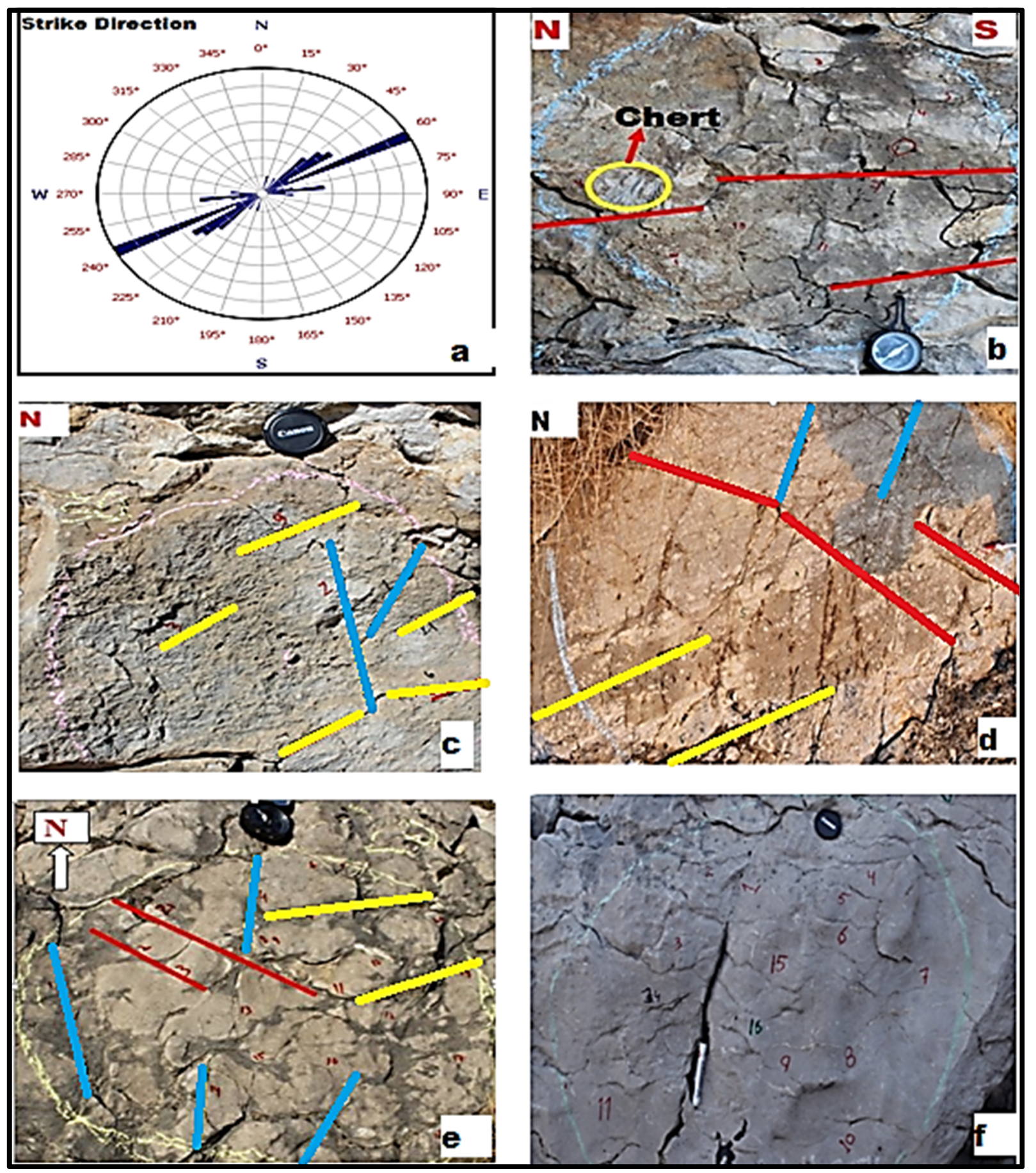

Fig. 4 Strike Direction and Field Photographs of Brittle deformation in the study area.

(a). Fractures trend in the study area (b). Less dense fractures with chert intercalations, parallel to the bedding plane (c). Moderately dense fracture network in Sakesar Limestone, fracture set3 (blue arrows) are inclined to the bedding plane, while yellow arrows indicating FS-2,3. (d). Outcrop photograph of shear fractures in Eocene Limestone. Yellow arrows indicating (FS-2) almost parallel to the bedding plane while blue arrows portraying FS-3(e). Highly dense complex fracture network; FS-3 (blue arrows), FS-1,2 (yellow arrows). (f). Close up view of Calcitic veins in Sakesar Limestone.

modification which describes that the direction of a slip in planar structure is parallel to the maximum shear stress of the reduced stress tensor (Simón, 2019; Tranos, 2015; Lisle, 2013; Kaven et al., 2011; Nemcok and Lisle, 1995; Lisle, 1987; Bott, 1959; Wallace, 1951). Comparable speculations could be furnished for various types of fractures namely contractional (perpendicular to the minimum stress (63)), extensional (perpendicular to the maximum principal stress (61)) produced in the response of a different type of stresses. These structural discontinuities are the precursor of the deformational events took place in 


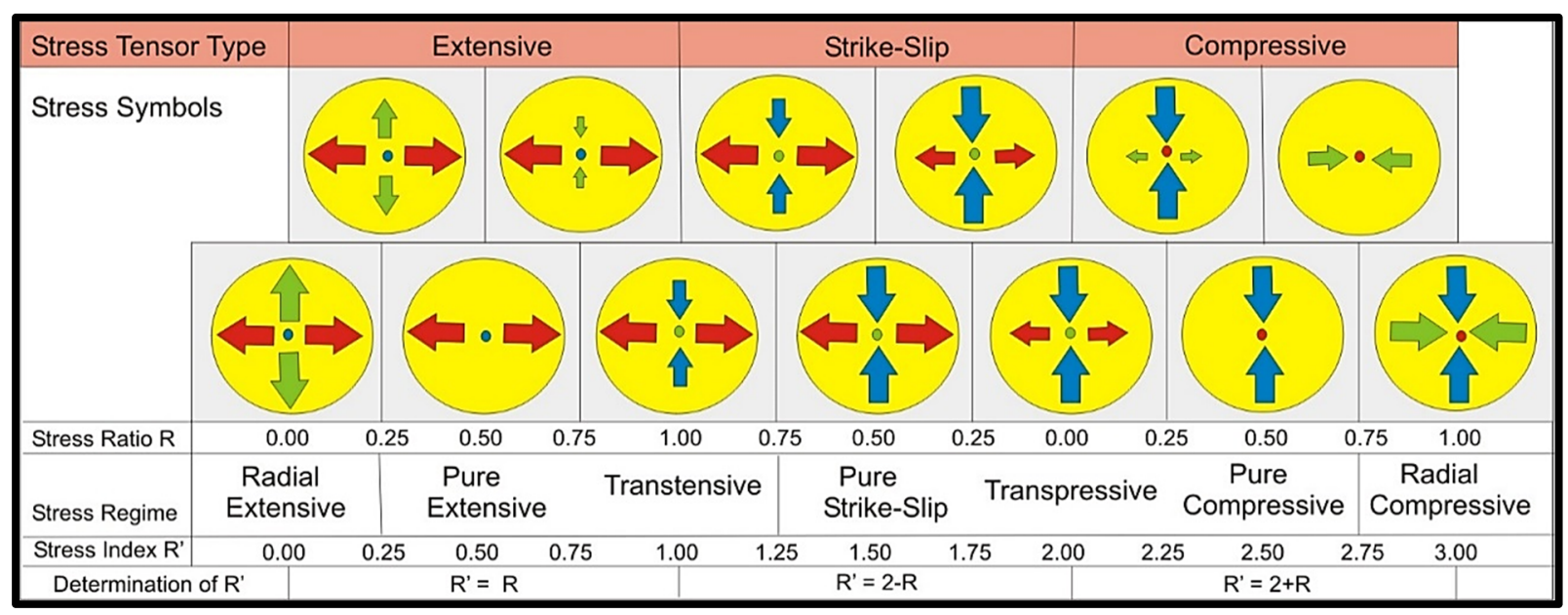

Fig. 5 Stress tensor representation for different stress settings (Modified after Delvaux et al., 1997).

the past (Ramsay and Lisle, 2000; Nemcok et al., 1999). Four mandatory parameters for the computation of reduced stress tensors are; 61 (maximum principal stress), $\sigma 2$ (intermediate stress axis), $\sigma 3$ (minimum stress axis), stress ratio $\mathrm{R}=(\sigma 2-\sigma 3) /(\sigma 1-\sigma 3)$. The other two parameters are principal stress magnitudes $(\sigma 1 / \sigma 3)$ and isotropic component which couldnot be calculated from the fault data (Igwe and Okonkwo, 2016; Angelier, 1994). The difference between stresses (stress ratio) $\mathrm{R}$ defines the shape of the ellipsoid. Major stress axes direction can only be inferred for the reduced stress tensors from inversion. The stress environment is characterized by the vertical stress axes; $\sigma 1$ vertical in case of the extensional regime, $\sigma 2$ vertical in strike-slip while $\sigma 3$ vertical in compressional tectonics. The three major stress regimes based on stress ratio (R) are expressed as; Radial Extension $(0<\mathrm{R}<0.25$, $\sigma 1$ perpendicular), Pure Extension (NF) Regime ( $\sigma 1$ Vertical, $0.25<\mathrm{R}<0.75$ ), Trans-tensional Regime ( $\sigma 2$ vertical, $0.75<\mathrm{R}<1$ ), Pure strike-slip (SS) settings $(0.75>\mathrm{R}>0.25$, 62 vertical), Transpression ( $\sigma 2$ vertical, $0.25>\mathrm{R}>0$ or $\sigma 3$ vertical, $0<\mathrm{R}<0.25$ ), Pure compressional (TF) settings ( $\sigma 3$ vertical, $0.25<\mathrm{R}<0.75)$ and in case of Radial compression ( 63 vertical, $0.75<\mathrm{R}<1$ ) (Delvaux and Sperner, 2003; Delvaux et al., 1997). Stress index R' determines the type of stress environment and ranges from 0.0 - 3.0. For extensional settings $\mathrm{R}^{\prime}=\mathrm{R}, \mathrm{R}$ ' $=2$ - $\mathrm{R}$ in strike-slip while $\mathrm{R}^{\prime}=2+\mathrm{R}$ in compressive settings. For the determination of regional stresses regime from the individual stress tenors in the prescribed area numeric values of stress index R' are very useful (Benkhelil, 1989) (Fig. 5).

\subsection{RESULTS}

The stress tensors were calculated from the data collected from seven locations selected for the best exposure of fracture network in the field (Table 2; Fig. 7). RDM was used for tensor determination by using fracture data. Around 86 (43 accepted) stress configurations constructed from the fracture data, among these $75 \%$ stress fields showed NNE-SSW to NE compression, while $20 \%$ fields represent NW-SE to NNW compression. The minor componenert of only $5 \%$ indicate E-W compression which not considered in the statistical analysis of the study. Detailed stress inversions results are shown in (Table 2; Fig. 7).

The first stress tensor solution from Nilawahan Gorge belongs to a radial compressional regime with $\sigma 1$ and $\sigma 2$ almost horizontal while $\sigma 3$ is sub-vertical (Table 1; Fig. 7a). The maximum shortening occurs in NE-SW direction with a stress index $\mathrm{R}^{\prime}=2.86$. At location namely Mallot (Fig. 7b), stress tensor 2 is calculated. Numeric stress parameters $(\sigma 1=00 / 207$, $\sigma 2=01 / 117, \quad \sigma 3=89 / 340)$ suggests oblique radial compressive settings ( $\sigma 1$ sub-horizontal, $\sigma 3$ subvertical) (Table 2; Fig. 7b). Stress index R' $=2.71$ shows maximum compression in NNE-SSW direction. At Katas Temple Road locality (Fig. 7c) stress tensor solution results show a compressive environment with $\sigma 1$ and $\sigma 2$ nearly horizontal while $\sigma 3$ is vertical. Maximum directed compression is estimated NNE to $\mathrm{NE}$ with stress ratio $\mathrm{R}=0.5$ (Fig. 7c). Tensor 4 results from locality ChoaSaidan Shah yield almost horizontal $\sigma 1, \sigma 2$ and sub-vertical $\sigma 3$ (Fig. 7d). The stress index $\left(R^{\prime}=2.73\right)$ shows a pure compressive regime with NW-SE oriented $\sigma 1$. The results show that $\sigma 1$ rotated from NNE-NE to NW at this locality. Stress tensor 5 results from the locality Saloi ( $\sigma 3$ subvertical, $\sigma 1$ sub-horizontal) suggesting a pure compressive environment with NE-SW oriented $\sigma 1$ (Fig. 7e).

Stress inversion results (Tensor 6) from locality named Takwan (Fig. 7f). Maximum directed compression in NE-SW direction with $\sigma 1$ and $\sigma 2$ almost horizontal while 63 is approx. vertical (Table 2). Numeric stress results show that tensor 6 almost on the verge of the radial compressive stress because of fractures aligned their-selves in the max principal stress direction along the major faults (Fig. 7f). Tensor 7 solution results from the locality Dil Jabba shows oblique radial compressive stress regime (stress index $\mathrm{R}^{\prime}=2.76$ ) with maximum directed compression in NE-SW direction (Table 2; Fig. 7g). 


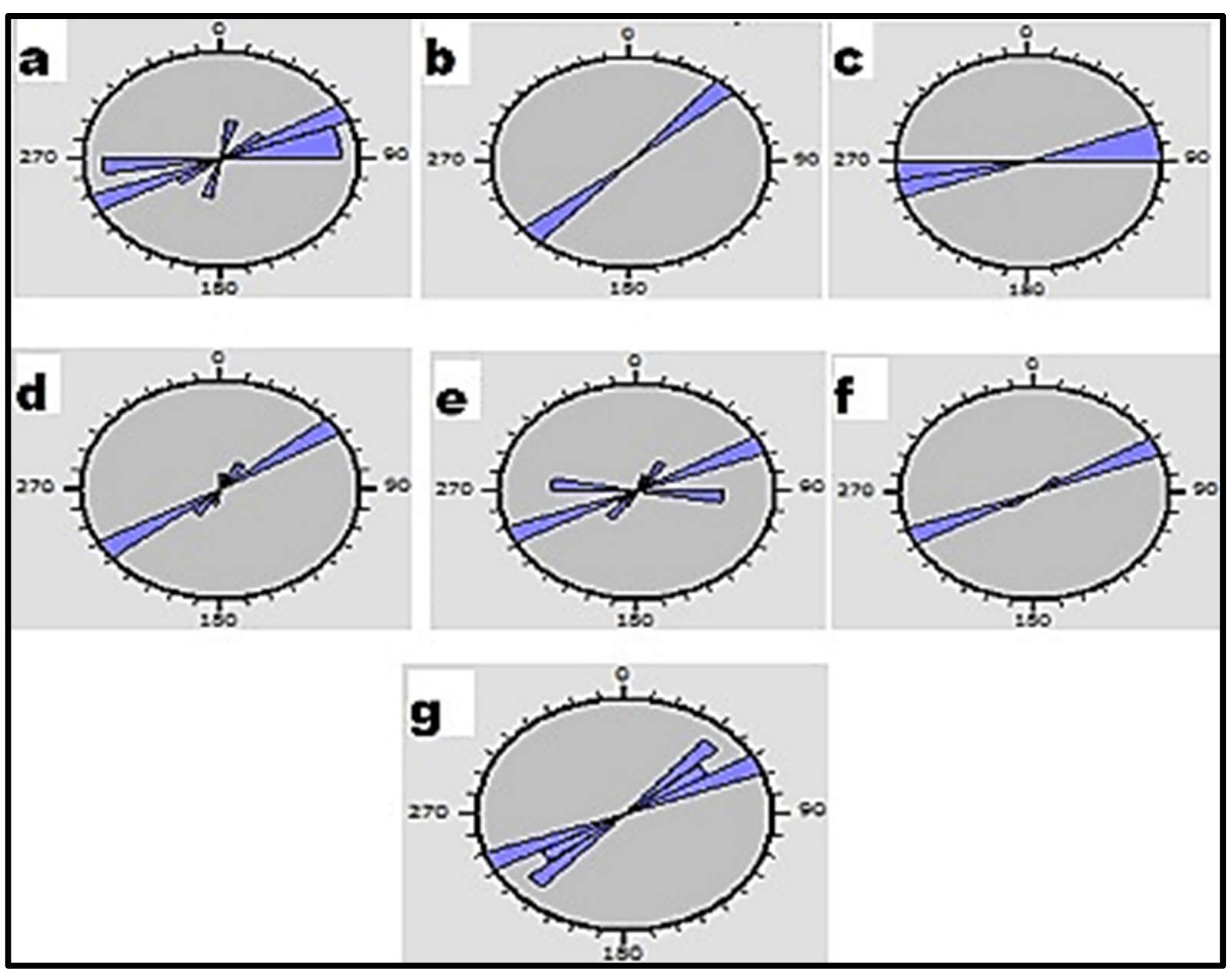

Fig. 6 Rose diagrams of the different fracture trends in the study area.

Table 2 Stress tensors detail of seven key locations of the study area.

\begin{tabular}{clcccccc}
\hline $\begin{array}{c}\text { Tensor } \\
\text { ID }\end{array}$ & \multicolumn{1}{c}{ Locality } & 61 & 62 & 63 & $\begin{array}{c}\text { Stress } \\
\text { Ratio (R) }\end{array}$ & $\begin{array}{c}\text { Stress } \\
\text { Index (R') }\end{array}$ & $\begin{array}{c}\text { Stress } \\
\text { Regime }\end{array}$ \\
\hline 1 & Nilawahan Gorge & $03 / 336$ & $12 / 326$ & $78 / 133$ & 0.97 & 2.86 & TF \\
2 & Mallot & $00 / 207$ & $01 / 117$ & $89 / 340$ & 0.5 & 2.71 & TF \\
3 & Katas Temple Road & $03 / 040$ & $04 / 309$ & $85 / 165$ & 0.5 & 2.71 & TF \\
4 & Choa Saidan Shah & $04 / 306$ & $10 / 215$ & $79 / 057$ & 0.5 & 2.73 & TF \\
5 & Saloi & $05 / 055$ & $01 / 145$ & $85 / 247$ & 0.5 & 2.69 & TF \\
6 & Takwan & $01 / 049$ & $08 / 319$ & $85 / 150$ & 0.67 & 2.71 & TF \\
7 & Dill Jabba & $04 / 051$ & $09 / 320$ & $80 / 166$ & 0.79 & 2.76 & TF \\
\hline
\end{tabular}

\section{DISCUSSION}

Paleostress inversion techniques have been extensively used by previous researchers (Simón, 2019; Lejri et al., 2017; Maerten et al., 2016; Tranos, 2015; Kaven et al., 2011; Kaymakci, 2006; Delvaux and Sperner, 2003; Ramsay and Lisle, 2000; Delvaux et al., 1997; Angelier and Mechler, 1977) for a long time and apply to numerous tectonic settings positively. Shear fractures are very important in terms of deformational history and are the best indicators of the slip sense similar to slickensides along faults (Grelle and Guadagno, 2010; Scheidegger et al.,
1998). Their orientations are the best indication of the stresses accumulated at the time of rock fracturing. Field data results and the compilations of the fracture sets (Table 1, Fig. 4) are used to understand the chronology of the structural events. The fracture set 1 (EW) and set 2 (ENE-WSW) are older fractures while set 3 is younger in age because they are developed almost orthogonal to the N-S directed Himalayan compression / shortening (McClay et al., 2004; Grelaud et al., 2002; Jaumé and Lillie, 1988). Fracture set 1 and set 2 are the originated as a result of the Himalayan induced deformation while set 3 are 

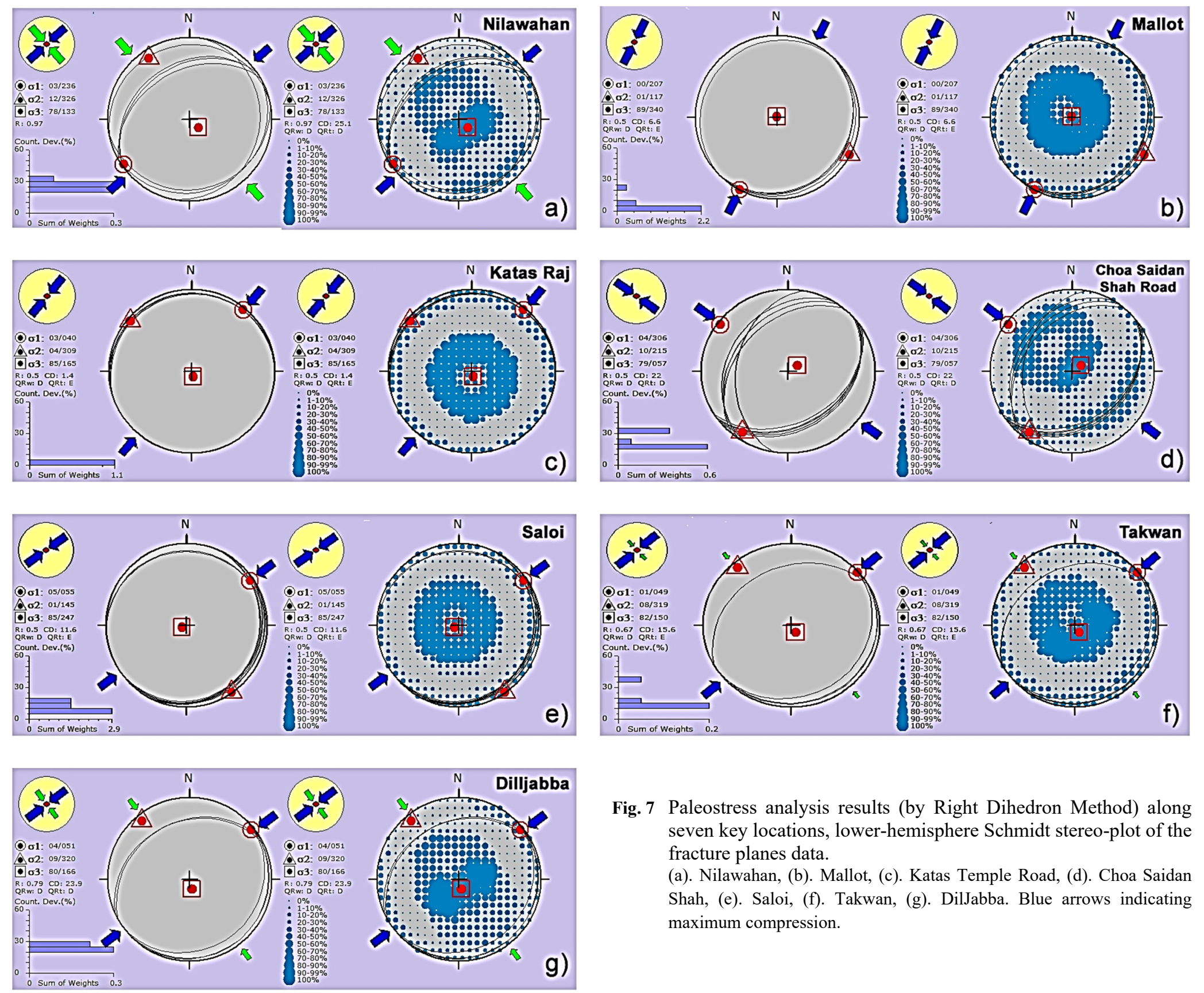

Fig. 7 Paleostress analysis results (by Right Dihedron Method) along seven key locations, lower-hemisphere Schmidt stereo-plot of the fracture planes data.

(a). Nilawahan, (b). Mallot, (c). Katas Temple Road, (d). Choa Saidan Shah, (e). Saloi, (f). Takwan, (g). DilJabba. Blue arrows indicating maximum compression. 


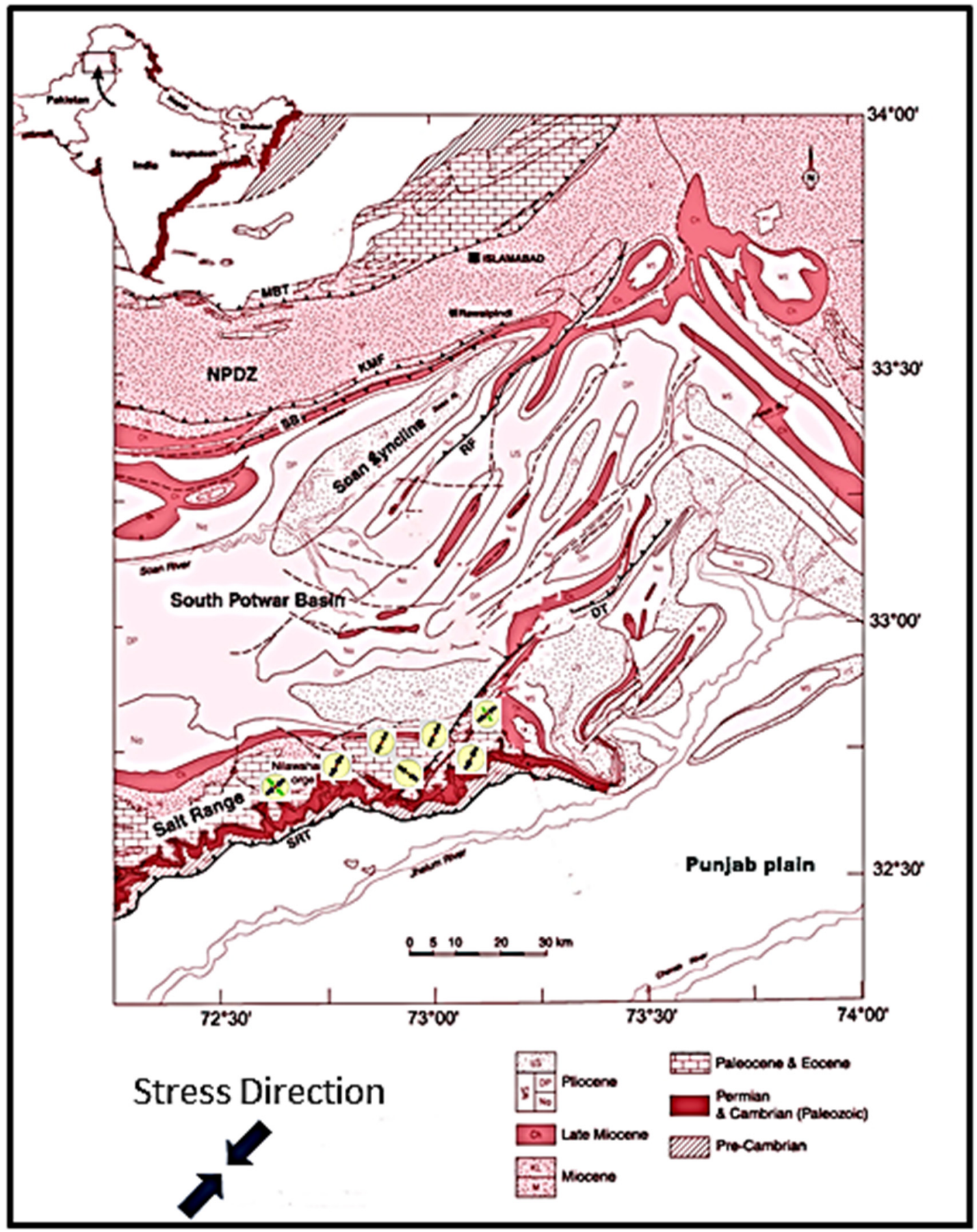

Fig. 8 Stress Tensors representation on the Geological Map of the Study Area (Modified after Grelaud et al., 2002).

produced as a result of local thrusting/faulting or migration of the salt in the subsurface. The Salt Range which makes the range front of the Himalayan fold and thrust belt is developed almost orthogonal ENE to the Himalayan induced NS deformation propogation. According to (Burbank and Beck, 1989; Pennock et al., 1989; Lillie et al., 1987; Yeats et al., 1984) tectonic evolution of the Salt Range occurred in two phases as considered; the first pulse in around $5 \mathrm{Ma}$, while later in $2 \mathrm{Ma}$ and the basin experienced maximum thrusting, uplift and erosion during Early Pliocene-Pleistocene times. The findings in Table 2 and Figure 7 shows pure compressive to radial compressive tectonic settings for the study area. $\sigma 1$ (max principal stress) and $\sigma 2$ are sub-horizontal while 63 (min principal stress) is subvertical in all paleostress tensors with 61 (Shmax) swinging around from NNE-NE to NNW-NW. Five out of seven paleostress tensors show pure compressive settings while 2 stations have a radial compressive regime. These stress tensors are mainly 
responsible for the NE-SW oriented structural discontinuities in the project area. The interesting fact about the abrupt change in the trend of the structural features (folds, faults, anticlines) from east-west in the Central Salt Range to northeast-southwest in the Eastern Salt Range (Gee and Gee, 1989; Jaumé and Lillie, 1988; Johnson et al., 1985) are aligned with the results.

No paleostress analysis has been done so far in the Salt Range, Potwar Plateau. Previous research conducted was about structural complexities underlain by Evaporites, time constraints, events of thrusting uplift and erosion by using seismic reflection data, cross-section balancing technique, gravity anomalies, drill holes and surface geology (Qayyum et al., 2015; Grelaud et al., 2002; Blisniuk et al., 1998; Burbank and Beck, 1989; Pennock et al., 1989; Baker et al., 1988; Burbank and Raynolds, 1988; Jaumé and Lillie, 1988; Butler et al., 1987; Leathers, 1987; Lillie et al., 1987; Yeats and Hussain, 1987; Johnson et al., 1986; Yeats et al., 1984; Yeats and Lawrence, 1982). Maximum principal stress (Shmax) rotation can cause by a change in lithology or angle of the fault. The rotation of maximum principal stress (Shmax) can also occur due to change in applied magnitude and direction of applied stress (Miraj, 2017, and reference herein). The eastern margin (study area) of the Salt Range experienced counter-clockwise stress rotations (Crawford, 1974) 30-40 reported by (Treloar et al., 1992; Jaumé and Lillie, 1988) which had changed the structural trends from ENE-WSW to NE-SW. Radial to obliques stress tensors shifts (Fig. 7) also witnessed the rotation of maximum principal stress (б1). Moreover, based on paleomagnetic data and fault kinematics $10^{\circ}$ to $30^{\circ}$ rotations are reported by (Qayyum, 2019 add thesis citation) The Hazara Kashmir Syntaxis, a syntaxial bend along major thrusts curved out along the strike (East of the Salt Range) development during Pliocene times (Treloar et al., 1992) also helpful to figure out structural complexities and time constraints in the tectonic evolution of the Eastern Salt Range.

Stress tensors orientations from failure planes in the response of triaxial stresses help to find max resolved shear stress and consequently its impact on deformation style in orogenic belts. In our results, max principal stress (๘1) obtained from reduced stress tensors is developed almost oblique to the SRT (ENE-trending, S-SSE verging) (Fig. 8) which is accountable for the late Quaternary thrusting and modified deformation style in the study area. While, in NW Himalaya (India) it is entirely different with NW trending, SW verging thrusts (Treloar et al., 1992). The Holocene shortening rates based on the GPS data and balanced cross-sections in NW Himalaya (Pakistan), Eastern Himalaya (India), and Central Himalaya (Nepal) along the HFT are $14 \pm 4 \mathrm{~mm} / \mathrm{yr}, 9 \pm 3 \mathrm{~mm} / \mathrm{yr}, 21 \pm 1.5 \mathrm{~mm} / \mathrm{yr}$ respectively. This shows an eastward increase of active deformation (slip rate) and ultimately India-Asian convergence rates along the HFT (Thakur, 2013; Burgess et al., 2012).

\section{CONCLUSIONS}

The present research is based on fracture analysis and paleostress inversion techniques to evaluate reduced stress tensors. Comprehensive field-based understanding of structural discontinuities and paleostress inversion analysis by using the Win Tensor ${ }^{\mathrm{TM}}$ tool from key seven locations inferred.

- Three significant fracture system (NE-SW, ENE-WNW, E-W) are reported from the field data.

- Field-based results show that fractures are mostly falls in the category of the shear/compressive domain.

- Locality wise results indicate pure compressive to a radial compressive tectonic regime.

- Paleostress inversion results reveal that the maximum principal compression (б1) occurs in the NNE-SSW direction that aligns with the rotation of the Salt Range thrust sheet in this section.

\section{ACKNOWLEDGEMENTS}

The current research work is the part of MS Geology of Hassan Mehmood completed in 2018 from the University of the Punjab, Lahore, Pakistan and submitted to Higher Education Commission (HEC) Pakistan for partial fulfilment of the degree. We would like to thank Mr. Kashif Abdullah and Mr. Hassaan Ali Zaidi for field data collection. We also acknowledge Mr. Rana Faizan Saleem for help with the graphics.

\section{REFERENCES}

Aleksandrowski, P.: 1985, Graphical determination of principal stress directions for slickenside lineation populations: an attempt to modify Arthaud's method. J. Struct. Geol., 7, 1, 73-82.

DOI: $10.1016 / 0191-8141(85) 90116-6$

Angelier, J.: 1984, Tectonic analysis of fault slip data sets. J. Geophys. Res., Solid Earth, 89, B7, 5835-5848. DOI: 10.1029/JB089iB07p05835

Angelier, J.: 1989, From orientation to magnitudes in paleostress determinations using fault slip data. J. Struct. Geol., 11, 1-2, 37-50.

DOI: 10.1016/0191-8141(89)90034-5

Angelier, J., Barrier, E. and Chu, H.T: 1986, Plate collision and paleostress trajectories in a fold-thrust belt: the foothills of Taiwan. Tectonophysics, 125, 1-3, 161178. DOI: 10.1016/0040-1951(86)90012-0

Angelier, J. and Mechler, P.: 1977, On a graphic method of research of the principal constraints also usable in tectonics and in seismology: The method of the right dihedrons. Bull. Soc. Géol. Fr., 7, 19, 1309-1318, (in French). DOI: 10.2113/gssgfbull.S7-XIX.6.1309

Angelier, J., Tarantola, A., Valette, B. and Manoussis, S.: 1982, Inversion of field data in fault tectonics to obtain the regional stressI. Single phase fault populations: a new method of computing the stress tensor. Geophys. J. Int., 69, 3, 607-621.

DOI: $10.1111 / j .1365-246 X .1982 . t b 02766 . x$ 
Baig, M.S. and Lawrence, R.D.: 1987, Precambrian to Early Paleozoic orogenesis in the Himalaya. Kashmir. J. Geol., 5, 1-22.

Baker, D.M., Lillie, R.J., Yeats, R.S., Johnson, G.D., Yousuf, M. and Zamin, A.S.H.: 1988, Development of the Himalayan frontal thrust zone: Salt range, Pakistan. Geology, 16, 1, 3-7. DOI:10.1130/0091-7613(1988)016

Bellahsen, N., Fiore, P. and Pollard, D.D: 2006, The role of fractures in the structural interpretation of Sheep Mountain Anticline, Wyoming. J. Struct. Geol., 28, 5, 850-867. DOI: 10.1016/j.jsg.2006.01.013

Benkhelil, J.: 1989, The origin and evolution of the Cretaceous Benue Trough (Nigeria). J. Afr. Earth Sci., $8,2-4,251-282$ DOI: $10.1016 / \mathrm{S} 0899-5362(89) 80028-4$

Blisniuk, P.M., Sonder, L.J. and Lillie, R.J.: 1998, Foreland normal fault control on northwest Himalayan thrust front development. Tectonics, 17, 5, 766-779. DOI: $10.1029 / 98 \mathrm{TC} 01870$

Bott, M.H.P.: 1959, The mechanics of oblique slip faulting. Geol. Mag., 96, 2, 109-117. DOI: $10.1017 / \mathrm{S} 0016756800059987$

Burgess, W.P., Yin, A., Dubey, C.S., Shen, Z.K. and Kelty, T.K.: 2012, Holocene shortening across the Main Frontal Thrust zone in the eastern Himalaya. Earth Planet. Sci. Let., 357, 152-167. DOI: 10.1016/j.eps1.2012.09.040

Burbank, D.W. and Beck, R.A.: 1989, Early Pliocene uplift of the Salt range; temporal constraints on thrust wedge development, northwest Himalaya, Pakistan. In: Malinconico, L.L. and Lillie, R.J. (eds), Tectonics of the Western Himalayas. Geol. Soc. Am., Spec Papers, 232, 113-128. DOI: 10.1130/SPE232-p113

Burbank, D.W. and Raynolds, R.G.H.: 1988, Stratigraphic keys to the timing of deformation: an example from the northwestern Himalayan foredeep. New perspectives in basin analysis. New York, SpringerVerlag, 331-351.

Butler, R.W., Coward, M.P., Harwood, G.M. and Knipe, R.J.: 1987, Salt control on thrust geometry, structural style and gravitational collapse along the Himalayan mountain front in the Salt Range of northern Pakistan. In: Dynamical geology of salt and related structures. Academic Press, 339-418.

DOI: 10.1016/B978-0-12-444170-5.50013-0

Célérier, B.: 1988, How much does slip on a reactivated fault plane constrain the stress tensor? Tectonics, 7, 6, 1257-1278. DOI: 10.1029/TC007i006p01257

Cortés-Aranda, J., Mugnier, J.L., Jouanne, F., Vassallo, R., Carcaillet, J. and Awan, A.A.: 2017, Holocene shortening rates and seismic hazard assessment for the frontal Potwar Plateau, NW Himalaya of Pakistan: Insights from $10 \mathrm{Be}$ concentrations on fluvial terraces of the Mahesian Anticline. Quatern. Int., 462, 75-89. DOI: 10.1016/j.quaint.2017.02.032

Coward, M.P., Butler, R.W.H., Chambers, A.F., Graham, R.H., Izatt, C.N., Khan, M.A., Knipe, R.J., Prior, D.J., Treloar, P.J. and Williams, M.P.: 1988, Folding and imbrication of the Indian crust during Himalayan collision. Philos. Trans. R. Soc. Lond.. Ser. A Math. Phys. Eng. Sci., 326, 1589, 89-116.

DOI: $10.1098 /$ rsta.1988.0081

Chatterjee, S., Goswami, A. and Scotese, C.R.: 2013, The longest voyage: tectonic, magmatic, and paleoclimatic evolution of the Indian plate during its northward flight from Gondwana to Asia. Gondwana Res., 23, 1, 238-267. DOI: 10.1016/j.gr.2012.07.001
Coward, M.P., Rex, D.C., Khan, M.A., Windley, B.F., Broughton, R.D., Luff, I.W., Petterson, M.G. and Pudsey, C.J.: 1986, Collision tectonics in the NW Himalayas. Geol. Soc. London, Spec. Publ., 19, 1, 203-219. DOI: 10.1144/GSL.SP.1986.019.01.11

Cotton, J.T. and Koyi, H.A.: 2000, Modeling of thrust fronts above ductile and frictional detachments: Application to structures in the Salt Range and Potwar Plateau, Pakistan. Geol. Soc. Am. Bull., 112, 3, 351-363. DOI: $10.1130 / 0016-7606(2000) 112$

Crawford, A.R.: 1974, The Salt Range, the Kashmir syntaxis and the Pamir arc. Earth Planet. Sci. Lett., 22, 4, 371379. DOI: $10.1016 / 0012-821 X(74) 90147$

Craig, J., Hakhoo, N., Bhat, G.M., Hafiz, M., Khan, M.R., Misra, R., Pandita, S.K., Raina, B.K., Thurow, J., Thusu, B. and Ahmed, W.: 2018, Petroleum systems and hydrocarbon potential of the North-West Himalaya of India and Pakistan. Earth Sci. Rev., 187, 109-185. DOI: 10.1016/j.earscirev.2018.09.012

Davies, R.G. and Crawford, A.R.: 1971, Petrography and age of the rocks of Bulland hill, Kirana hills, Sarghoda District, West Pakistan. Geol. Mag., 108, 3, 235-246. DOI: $10.1017 / \mathrm{S} 001675680005158 \mathrm{X}$

Delvaux, D. and Sperner, B.: 2003, New aspects of tectonic stress inversion with reference to the TENSOR program. Geol. Soc. London Spec. Publ., 212, 1, 75100. DOI: 10.1144/GSL.SP.2003.212.01.06

Delvaux, D., Moeys, R., Stapel, G., Petit, C., Levi, K., Miroshnichenko, A., Ruzhich, V. and San'kov, V.: 1997, Paleostress reconstructions and geodynamics of the Baikal region, Central Asia, Part 2. Cenozoic rifting. Tectonophysics, 282, 1-4, 1-38. DOI: $10.1016 / \mathrm{S} 0040-1951(97) 00210-2$

DiPietro, J.A. and Pogue, K.R.: 2004, Tectonostratigraphic subdivisions of the Himalaya: A view from the west. Tectonics, 23, 5. DOI: 10.1029/2003TC001554

Engelder, T.: 1987, Joints and shear fractures in rock. Fracture Mechanics of Rock. Academic Press London, 27-69. DOI: 10.1016/b978-0-12-066266-1.50007-7

Etchecopar, A., Vasseur, G. and Daignieres, M.: 1981, An inverse problem in microtectonics for the determination of stress tensors from fault striation analysis. J. Struct. Geol., 3, 1, 51-65. DOI: $10.1016 / 0191-8141(81) 90056-0$

Friedman, M.: 1975, Fracture in rock. Rev. Geophys., 13, 3, 352-358. DOI: 10.1029/RG013i003p00352

Frizzell Jr., V.A. and Zoback, M.L.: 1987, Stress orientation determined from fault slip data in Hampel Wash area, Nevada, and its relation to contemporary regional stress field. Tectonics, 6, 2, 89-98. DOI: $10.1029 /$ TC006i002p00089

Gansser, A.: 1964, Geology of the Himalayas. InterScience, New York, 289 pp.

Gansser, A.: 1981, The geodynamic history of the Himalaya. Zagros Hindu Kush Himalaya Geodynamic Evolution, 3, 111-121. DOI: 10.1029/GD003p0111

Gee, E.R.: 1945, The age of the Saline series of the Punjab and of Kohat. Proc. National Academy of Science India, 14, 269-310.

Gee, E.R.: 1980, Salt Range series geological maps. Directorate of Overseas Surveys, United Kingdom, for the Government of Pakistan and Geological Survey of Pakistan, 6.

Gee, E.R. and Gee, D.G.: 1989, Overview of the geology and structure of the Salt Range, with observations on related areas of northern Pakistan. Geol. Soc. Am. Special Papers, 232, 95-112. DOI: 10.1130/SPE232-p95 
Grelaud, S., Sassi, W., de Lamotte, D.F., Jaswal, T. and Roure, F.: 2002, Kinematics of eastern Salt Range and South Potwar basin (Pakistan): a new scenario. Mar. Pet. Geol., 19, 9, 1127-1139. DOI: $10.1016 / \mathrm{S} 0264-8172(02) 00121-6$

Grelle, G. and Guadagno, F.M.: 2010, Shear mechanisms and viscoplastic effects during impulsive shearing. Géotechnique, 60, 2, 91. DOI: 10.1680/geot.8.P.019

Guiraud, M.: 1993, Late Jurassic rifting-early Cretaceous rifting and late Cretaceous transpressional inversion in the upper Benue basin (NE Nigeria). Bull. Centres Rech. Explor.-Prod. Elf-Aquitaine, 17, 2, 371-383.

Handin, J., Hager Jr., R.V., Friedman, M. and Feather, J.N.: 1963, Experimental deformation of sedimentary rocks under confining pressure: pore pressure tests. Am. Assoc. Pet. Geol. Bull., 47, 5, 717-755. DOI:10.1306/BC743A87-16BE-11D7$8645000102 \mathrm{C} 1865 \mathrm{D}$

Hancock, P.L.: 1985, Brittle microtectonics: principles and practice. J. Struct. Geol., 7, 3-4, 437-457. DOI: 10.1016/0191-8141(85)90048-3

Hodges, K.V.: 2000, Tectonics of the Himalaya and southern Tibet from two perspectives. Geol. Soc. Am. Bull., 112, 3, 324-350. DOI: 10.1130/0016-7606(2000)112

Hughes, N.C., Myrow, P.M., Ghazi, S., McKenzie, N.R., Stockli, D.F. and DiPietro, J.A.: 2019, Cambrian geology of the Salt Range of Pakistan: Linking the Himalayan margin to the Indian craton. Bulletin, 131, 7-8, 1095-1114. DOI: 10.1130/B35365.1

Hugman III, R.H.H. and Friedman, M.: 1979, Effects of texture and composition on mechanical behavior of experimentally deformed carbonate rocks. Am. Assoc. Pet. Geol. Bull., 63, 9, 1478-1489. DOI: 10.1306/2F9185C7-16CE-11D7-8645000102C1865D

Igwe, O. and Okonkwo, I.A.: 2016, Application of paleostress analysis for the identification of potential instability precursors within the Benue Trough Nigeria. Geoenvironmental Disasters, 3, 1, 17. DOI: 10.1186/s40677-016-0051-z

Ingalls, M., Rowley, D.B., Currie, B. and Colman, A.S.: 2016, Large-scale subduction of continental crust implied by India-Asia mass-balance calculation. Nat. Geosci., 9, 11, 848. DOI: 10.1038/ngeo2806

Jadoon, I.A.K., Frisch, W., Kemal, A. and Jaswal, T.M.: 1997, Thrust geometries and kinematics in the Himalayan foreland (North Potwar deformed zone), North Pakistan. Geol. Rundsch., 86, 1, 120-131.

Jaumé, S.C. and Lillie, R.J.: 1988, Mechanics of the Salt Range-Potwar Plateau, Pakistan: A fold-and-thrust belt underlain by evaporites. Tectonics, 7, 1, 57-71. DOI: 10.1029/TC007i001p00057

Johnson, G.D., Raynolds, R.G. and Burbank, D.W.: 1986, Late Cenozoic tectonics and sedimentation in the north-western Himalayan foredeep: I. Thrust ramping and associated deformation in the Potwar region. In: Allen, P.A. and Homedwood, P.M, eds., Foreland Basins, 8. Belgium, Blackwell Publishing, 273-291. DOI: 10.1002/9781444303810.ch15

Johnson, N.M., Stix, J., Tauxe, L., Cerveny, P.F. and Tahirkheli, R.A.: 1985, Paleomagnetic chronology, fluvial processes, and tectonic implications of the Siwalik deposits near Chinji village, Pakistan. J. Geol., 93, 1, 27-40. DOI: 10.1086/628917

Kaven, J.O., Maerten, F. and Pollard, D.D.: 2011, Mechanical analysis of fault slip data: Implications for paleostress analysis. J. Struct. Geol., 33, 2, 78-91. DOI: $10.1016 /$ j.jsg.2010.12.004
Kaymakci, N.: 2006, Kinematic development and paleostress analysis of the Denizli Basin (Western Turkey): implications of spatial variation of relative paleostress magnitudes and orientations. J. Asian Earth Sci., 27, 2, 207-222.

DOI: $10.1016 /$ j.jseaes.2005.03.003

Kazmi, A.H. and Rana, R.A.: 1982, Tectonic map of Pakistan 1:2 000 000: Map showing structural features and tectonic stages in Pakistan. Geological Survey of Pakistan.

Khan, S.D., Chen, L., Ahmad, S., Ahmad, I. and Ali, F.: 2012, Lateral structural variation along the Kalabagh Fault Zone, NW Himalayan foreland fold-and-thrust belt, Pakistan. J. Asian Earth Sci., 50, 79-87. DOI: 10.1016/j.jseaes.2012.01.009

Lacombe, O., Bellahsen, N. and Mouthereau, F.: 2011, Fracture patterns in the Zagros Simply Folded Belt (Fars, Iran): constraints on early collisional tectonic history and role of basement faults. Geol. Mag., 148, 5-6, 940-963. DOI: 10.1017/S001675681100029X

Leathers, M.R.: 1987, Balanced structural cross section of the western Salt Range and Potwar Plateau, Pakistan: deformation near the strike-slip terminus of an overthrust sheet. Master Dissertation.

Lejri, M., Maerten, F., Maerten, L. and Soliva, R.: 2017, Accuracy evaluation of both Wallace-Bott and BEMbased paleostress inversion methods. Tectonophysics, 694, 130-145. DOI: 10.1016/j.tecto.2016.11.039

Lillie, R.J., Johnson, G.D., Yousuf, M., Zamin, A.S.H. and Yeats, R.S.: 1987, Structural development within the Himalayan foreland fold-and-thrust belt of Pakistan.

Lisle, R.J.: 1987, Principal stress orientations from faults: an additional constraint. Annales Tectonicae, 1, 2, 155158.

Lisle, R.J.: 1988, ROMSA: a BASIC program for paleostress analysis using fault-striation data. Comput. Geosci., 14, 2, 255-259. DOI: 10.1016/0098-3004(88)90007-6I

Lisle, R.J.: 2013, A critical look at the Wallace-Bott hypothesis in fault-slip analysis. Bull. Soc. Géol. Fr., 184, 4-5, 299-306. DOI: $10.2113 /$ gssgfbull.184.4-5.299

Maerten, L., Maerten, F., Lejri, M. and Gillespie, P.: 2016, Geomechanical paleostress inversion using fracture data. J. Struct. Geol., 89, 197-213. DOI: $10.1016 /$ j.jsg.2016.06.007

McClay, K.R., Whitehouse, P.S., Dooley, T. and Richards, M.: 2004, 3D evolution of fold and thrust belts formed by oblique convergence. Mar. Pet. Geol., 21, 7, 857877. DOI: $10.1016 / \mathrm{S} 0264-8172(04) 00056$

McDougall, J.W. and Khan, S.H.: 1990, Strike-slip faulting in a foreland fold-thrust belt: The Kalabagh Fault and Western Salt Range, Pakistan. Tectonics, 9, 5, 10611075. DOI: $10.1029 /$ TC009i005p01061

McKenzie, D.P.: 1969, The relation between fault plane solutions for earthquakes and the directions of the principal stresses. Bull. Seismol. Soc. Am., 59, 2, 591-601.

Meigs, A.J., Burbank, D.W. and Beck, R.A.: 1995, Middlelate Miocene $(>10 \mathrm{Ma})$ formation of the Main Boundary thrust in the western Himalaya. Geology, 235, 423-426. DOI: 10.1130/0091-7613(1995)023

Michael, A.J.: 1984, Determination of stress from slip data: faults and folds. J. Geophys. Res., Solid Earth, 89, B13, 11517-11526. DOI: 10.1029/JB089iB13p11517

Miraj, M.A.F.: 2017, Structural analysis of inversion features of the Barents Sea. Doctoral Dissertation, Ruhr-Universität Bochum. 
Molnar, P.: 1986, The geologic history and structure of the Himalaya. Am. Sci., 74, 144-154.

Molnar, P. and Tapponnier, P.: 1977, The collision between India and Eurasia. Sci. Am., 236, 4, 30-41. DOI: $10.1038 /$ scientificamerican0477-30

Mugnier, J.L. and Huyghe, P.: 2006, Ganges basin geometry records a pre- $15 \mathrm{Ma}$ isostatic rebound of Himalaya. Geology, 34, 445-448. DOI: 10.1130/G22089.1

Myrow, P.M., Hughes, N.C. and McKenzie, N.R.: 2019, Reconstructing the Himalayan margin prior to collision with Asia: Proterozoic and lower Paleozoic geology and its implications for Cenozoic tectonics. Geol. Soc. London Spec. Publ., 483, 1, 3964. DOI: $10.1144 / \mathrm{SP} 483.10$

Nelson, R.: 2001, Geologic analysis of naturally fractured reservoirs. Elsevier.

Nemcok, M.: 1995, A stress inversion procedure for polyphase fault/slip data sets. J. Struct. Geol., 17, 10, 1445-1453. DOI: 10.1016/0191-8141(95)00040-K

Nemcok, M., Kovác, D. and Lisle, R.J.: 1999, A stress inversion procedure for polyphase calcite twin and fault/slip data sets. J. Struct. Geol., 21, 6, 597-611. DOI: 10.1016/S0191-8141(99)00053-X

Patriat, P. and Achache, J.: 1984, India-Eurasia collision chronology has implications for crustal shortening and driving mechanism of plates. Nature, 311, 5987, 615 . DOI: $10.1038 / 311615 \mathrm{a} 0$

Pennock, E.S., Lillie, R.J., Zaman, A.S.H. and Yousaf, M.: 1989, Structural interpretation of seismic reflection data from eastern Salt Range and Potwar Plateau, Pakistan. Am. Assoc. Pet. Geol. Bull., 73, 7, 841-857. DOI: 10.1306/44B4A27B-170A-11D7-8645000102C1865D

Powell, C.M.: 1979, A speculative tectonic history of Pakistan and surroundings. In: Dejong, K. and Farah, A., Eds., Geodynamics of Pakistan. Quetta, 5-24

Powell, C.M. and Conaghan, P.J.: 1973, Plate tectonics and the Himalayas. Earth Planet. Sci. Lett., 20, 1, 1-12. DOI: $10.1016 / 0012-821 X(73) 90134-9$

Qayyum, A.: 2018, Tectonic development of Potwar Plateau and the saltrange (NW Himalayas, Pakistan). EGU2018.

Qayyum, M., Spratt, D.A., Dixon, J.M. and Lawrence, R.D.: 2015, Displacement transfer from fault-bend to faultpropagation fold geometry: an example from the Himalayan thrust front. J. Struct. Geol., 77, 260-276. DOI: $10.1016 /$ j.jsg.2014.10.010

Ramsay, J.G. and Lisle, R.J.: 2000, Applications of continuum mechanics in structural geology. Techniques of modern structural geology, 3 . Academic Press.

Scheidegger, A.E.: 1998, Tectonic predesign of mass movements, with examples from the Chinese Himalaya. Geomorphology, 26, 1-3, 37-46. DOI: 10.1016/S0169-555X(98)00050-6

Searle, M.P., Windley, B.F., Coward, M.P., Cooper, D.J.W., Rex, A.J., Rex, D., Tingdong, L., Xuchang, X., Jan, M.Q., Thakur, V.C. and Kumar, S.: 1987, The closing of Tethys and the tectonics of the Himalaya. Geol. Soc. Am. Bull., 98, 6, 678-701. DOI: $10.1130 / 00167606(1987) 98$

Searle, M.P. and Treloar, P.J.: 2019, An introduction to Himalayan tectonics: a modern synthesis. Geol. Soc. London Spec. Publ., 483, 1-17.

DOI: $10.1144 /$ SP483-2019-20

Shah, S.I.: 1977, Stratigraphy of Pakistan. Geol. Surv. Pakistan, 12.
Simón, J.L.: 2019, Forty years of paleostress analysis: has it attained maturity? J. Struct. Geol., 125, 124-133. DOI: $10.1016 /$ j.jsg.2018.02.011

Tahirkheli, R.K.: 1979, The India-Eurasia suture zone in northern Pakistan: Synthesis and interpretation of recent data at plate scale. Geodynamics of Pakistan, $125-130$.

Tahirkheli, R.K.: 1982, Geology of the Himalaya, Karakoram and Hindukush in Pakistan. Geol. Bull. Univ. Peshawar, 15, 1-51.

Tapponnier, P., Peltzer, G. and Armijo, R.: 1986, On the mechanics of the collision between India and Asia. Geol. Soc. London Spec. Publ., 19, 1. DOI: 113-157.10.1144/GSL.SP.1986.019.01.07

Thakur, V.C.: 2013, Active tectonics of Himalayan frontal fault system. Int. J. Earth Sci., 102, 7, 1791-1810. DOI: $10.1007 / \mathrm{s} 00531-013-0891-7$

Tranos, M.D.: 2015, TR method (TRM): A separation and stress inversion method for heterogeneous fault-slip data driven by Andersonian extensional and compressional stress regimes. J. Struct. Geol., 79, 5774. DOI: 10.1016/j.jsg.2015.07.006

Treloar, P.J., Coward, M.P., Chambers, A.F., Izatt, C.N. and Jackson, K.C.: 1992, Thrust geometries, interferences and rotations in the northwest Himalaya. Thrust Tectonics. Springer, Dordrecht, 325-342.

DOI: 10.1007/978-94-011-3066-0_30

Van Hinsbergen, D.J., Lippert, P.C., Dupont-Nivet, G., McQuarrie, N., Doubrovine, P.V., Spakman, W. and Torsvik, T.H.: 2012, Greater India Basin hypothesis and a two-stage Cenozoic collision between India and Asia. Proc. Nat. Acad. Sci., 109, 20, 7659-7664. DOI: $10.1073 /$ pnas. 1117262109

Wallace, R.E.: 1951, Geometry of shearing stress and relation to faulting. J. Geol., 59, 2, 118-130. DOI: $10.1086 / 625831$

Yeats, R.S. and Hussain, A.: 1987, Timing of structural events in the Himalayan foothills of northwestern Pakistan. Geol. Soc. Am. Bull., 99, 2, 161-176. DOI: 10.1130/0016-7606(1987)99

Yeats, R.S., Khan, S.H. and Akhtar, M.: 1984, Late quaternary deformation of the Salt Range of Pakistan. Geol. Soc. Am. Bull., 95, 8, 958-966. DOI: $10.1130 / 0016-7606(1984) 95$

Yeats, R.S. and Lawrence, R.D.: 1982, Tectonics of the Himalayan thrust belt in northern Pakistan. USPakistan Workshop on Marine Sciences in Pakistan, Karachi, Pakistan, Nov. 11-16, 1982, 39 pp.

Yin, A.: 2010, Cenozoic tectonic evolution of Asia: A preliminary synthesis. Tectonophysics, 488, 14, 293-325. DOI: 10.1016/j.tecto.2009.06.002 